\title{
Aplikasi Multimedia sebagai Media Pembelajaran Ilmu Pengetahuan Sosial Materi Budaya di Indonesia menggunakan Unity Engine untuk Sekolah Dasar
}

\author{
Ade Riyantika Dewi ${ }^{1)}$, R. Rizal Isnanto ${ }^{2)}$, Kurniawan Teguh Martono ${ }^{2)}$ \\ Program Studi Sistem Komputer Fakultas Teknik Universitas Diponegoro \\ Jalan Prof. Sudharto, Tembalang, Semarang, Indonesia \\ aderiyantika@gmail.com
}

\begin{abstract}
Abstrak - Belajar merupakan kegiatan pokok yang dilakukan di sekolah, khususnya untuk seorang pelajar. Seorang pelajar harus memperhatikan penjelasan materi pelajaran yang diberikan oleh guru. Namun saat ini guru hanya menjelaskan materi pelajaran dengan metode konvensional, sehingga pelajar menjadi kurang aktif karena hanya memperhatikan dan mendengarkan saja. Metode ini berdampak pada semangat belajar pelajar yang menurun karena merasa bosan dengan metode-metode seperti itu saja. Seharusnya dengan perkembangan teknologi masa kini, guru dapat memanfaatkannya untuk meningkatkan semangat belajar pelajar secara efisien dan mandiri serta mengajarkan siswa untuk berperan aktif dalam pembelajaran. Berdasarkan permasalahan tersebut dibangun sebuah aplikasi multimedia pembelajaran interaktif berbasis mobile sebagai pendamping pembelajaran untuk dapat menunjang proses penerimaan materi pelajaran di sekolah.
\end{abstract}

Aplikasi multimedia pembelajaran pendamping tersebut dibuat menggunakan Unity Engine 5.0, dan Adobe Illustrator. Metode pengembangan mutimedia yang digunakan adalah Multimedia Development Life Cycle (MDLC) . Untuk metode pengujian aplikasi menggunakan metode Black Box Testing dan Betha Testing yang berupa kuesioner.

Hasil Black Box Testing dari aplikasi multimedia pembelajaran pendamping berbasis mobile dengan Unity Engine ini menunjukkan bahwa semua fungsi menu yang terdapat pada aplikasi telah berhasil sesuai dengan fungsinya. Hasil Betha Testing menunjukkan bahwa lebih dari $75 \%$ responden memberikan respon positif terhadap aplikasi. Aplikasi dapat dikategorikan baik, sehingga aplikasi dapat digunakan sebagai media pendamping pembelajaran di sekolah maupun di luar sekolah.

Kata kunci : Aplikasi Multimedia Pembelajaran, Unity Engine, Multimedia Development Life Cycle (MDLC), Budaya Indonesia.

\section{PENDAHULUAN}

Sekolah merupakan tempat utama menuntut ilmu bagi seorang pelajar. Pelajar mendapatkan ilmu dengan bantuan guru sebagai media penyampaian materi. Metode penyampaian yang dilakukan oleh guru masih menggunakan cara yang konvensional. Metode tersebut menjadi salah satu faktor yang dapat menurunkan semangat belajar siswa karena merasa bosan karena hanya memperhatikan dan mendengarkan guru saja. Seharusnya dengan teknologi yang ada saat ini, guru dapat membuat metode belajar siswa lebih aktif dan menyenangkan, namun karena faktor usia guru serta sikap guru yang memang belum bisa menerima perkembangan teknologi jarang sekali mau mengajar menggunakan teknologi dengan alasan tidak bisa atau dianggap merepotkan, padahal dengan memanfaatkan teknologi pembelajaran teori dapat lebih maksimal.

Berdasarkan latar belakang di atas, maka permasalahan yang diangkat dalam penelitian ini yaitu.
“ Bagaimana merancang dan membuat aplikasi sebagai pendamping pembelajaran yang interaktif mengenai materi Budaya setiap provinsi di Indonesia untuk Sekolah Dasar ? “

"Dapatkah media pembelajaran interaktif digunakan sebagai alternatif pembelajaran yang menyenangkan ?'

Dalam pembuatan tugas akhir ini pembahasan masalah memiliki batasan pada permasalahan berikut :

a. Materi yang dibahas adalah materi Budaya yang meliputi rumah adat, alat musik daerah dan pakaian adat setiap provinsi di Indonesia pada mata pelajaran Ilmu Pengetahuan Sosial (IPS) Sekolah Dasar (SD).

b. Multimedia pembelajaran dibuat dengan menggunakan Unity Engine 5, dan Adobe Illustrator serta berbasis Android.

Tugas akhir ini mempunyai beberapa tujuan, yaitu:

a. Pembuatan aplikasi media sebagai pendamping pembelajaran menggunakan Unity Engine dalam pembelajaran Ilmu Pengetahuan Sosial materi Budaya yang meliputi rumah, alat musik, dan pakaian adat setiap Provinsi di Indonesia untuk Sekolah Dasar.

b. Menerapkan aplikasi multimedia pembelajaran interaktif sebagai alternatif pembelajaran yang menyenangkan untuk siswa di sekolah maupun diluar sekolah.

\section{LANDASAN TEORI}

A. Media Pembelajaran

Media berasal dari bahasa latin merupakan bentuk jamak dari "Medium" yang secara harfiah berarti "Perantara" atau "Pengantar" yaitu perantara atau pengantar sumber pesan dengan penerima pesan ${ }^{[5]}$. Sebagai penyaji dan penyalur pesan, media belajar dalam hal-hal tertentu bisa mewakili guru menyajikan informasi belajar kepada siswa. Jika program media itu didesain dan dikembangkan secara baik, maka fungsi itu akan dapat diperankan oleh media meskipun tanpa keberadaan guru. Sedangkan pembelajaran merupakan kegiatan yang melibatkan penambahan informasi pada memori seseorang.

B. Materi IPS mengenai budaya Indonesia

Ilmu Pengetahuan Sosial di Sekolah Dasar memuat materi pembelajaran mengenai budaya yang muncul pada masyarakat. Budaya sendiri berasal dari bahasa Sansekerta yaitu buddhayah, yang merupakan bentuk jamak dari buddhi (budi atau akal) diartikan sebagai hal-hal yang berkaitan dengan budi dan akal manusia ${ }^{[8]}$. Indonesia memiliki berbagai wujud kebudayaan daerah yang meliputi Rumah adat, pakaian adat, alat musik dan sebagainya ${ }^{[9]}$. Berikut ini beberapa seni daerah di Indonesia.

1. Rumah Adat 
Rumah Adat adalah bangunan yang memiliki ciri khas khusus, digunakan untuk tempat hunian oleh suatu suku bangsa tertentu. Indonesia menjadikan rumah adat sebagai hasil karya yang disengaja dipertahankan dan dilestarikan sebagai simbol budaya Indonesia. Indonesia memiliki jumlah Provinsi sebanyak 34 dengan berbagai macam jenis rumah adat.

2. Pakaian Adat

Pakaian Adat merupakan simbol kebudayaan suatu daerah. Untuk menunjukkan nama daerah pakaian adat pun dapat dijadikan simbol tersebut. Setiap daerah memiliki pengertian pakaian adat sendiri-sendiri. Sebagai simbol, pakaian adat memang dijadikan penanda untuk sesuatu.

3. Alat Musik Daerah

Identitas musik Indonesia mulai terbentuk ketika budaya Zaman Perunggu bermigrasi ke Nusantara pada abad ketiga dan kedua sebelum Masehi. Musik suku tradisional Indonesia umumnya menggunakan instrumen perkusi, terutama gendang dan gong. Beberapa berkembang menjadi musik yang rumit dan berbeda-beda, seperti alat musik petik sasando dari Pulau Rote, angklung dari Jawa Barat, dan musik orkestra gamelan yang kompleks dari Jawa dan Bali

\section{Multimedia}

Multimedia merupakan kombinasi teks, seni, suara, gambar, animasi, dan video yang disampaikan dengan komputer atau dimanipulasi secara digital dan dapat disampaikan dan/atau dikontrol secara interaktif ${ }^{[4]}$.

Dari definisi di atas, sebuah sistem multimedia dapat digambarkan seperti pada Gambar 1

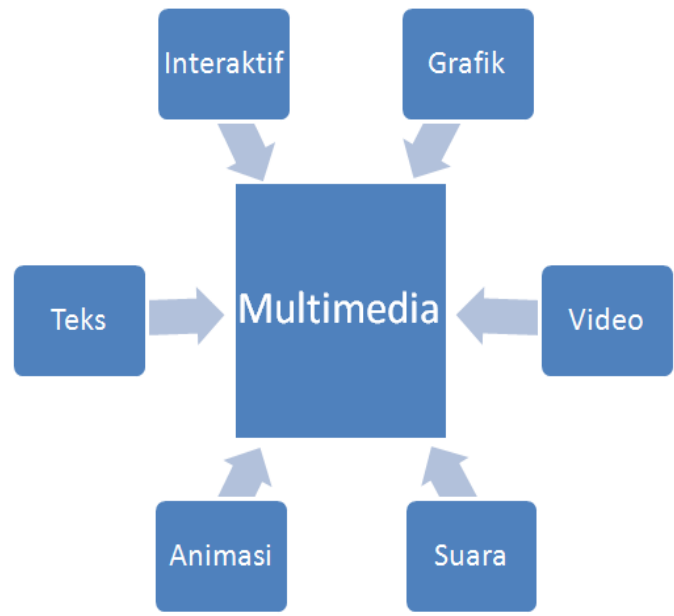

Gambar 1. Gambaran multimedia ${ }^{[11]}$.

\section{Multimedia Pembelajaran Interaktif}

Multimedia interaktif adalah suatu multimedia yang dilengkapi dengan alat pengontrol yang dapat dioperasikan oleh pengguna, sehingga pengguna dapat memilih apa yang dikehendaki untuk proses selanjutnya. Contoh: multimedia interaktif adalah pembelajaran interaktif, aplikasi permainan [14]. Sedangkan pembelajaran diartikan sebagai proses penciptaan lingkungan yang memungkinkan terjadinya proses belajar.
Penggunaan komputer untuk kegiatan pembelajaran, akhir-akhir ini semakin banyak dimanfaatkan oleh dunia pendidikan. Hal ini menunjukkan media komputer sangat memungkinkan terjadinya proses belajar mengajar yang lebih efektif. Hal ini terjadi karena dengan sifat dan karakteristik komputer yang cukup khas.

Bentuk-bentuk pemanfaatan model-model multimedia interaktif berbasis komputer dalam pembelajaran dapat berupa drill, tutorial, simulation, dan games ${ }^{[2]}$. Pada dasarnya salah satu tujuan pembelajaran dengan multimedia interaktif adalah sedapat mungkin dan atau melengkapi serta mendukung unsur-unsur : tujuan, materi, metode dan alat penilaian yang ada dalam proses belajar mengajar dalam sistem pendidikan konvensional yang biasa dilakukan.

\section{E. Unity Engine}

Unity merupakan salah satu game engine yang banyak digunakan. Unity menyediakan fitur pengembangan game dalam berbagai platform, yaitu Unity Web, Windows, Mac, Android, iOS, XBox, Playstation 3 dan Wii.

Dalam unity disediakan berbagai pilihan bahasa pemrograman untuk mengembangkan game, antara lain JavaScript, C\#, dan BooScript. Namun meskipun disediakan tiga bahasa pemrograman, kebanyakan pengembang menggunakan JavaScript dan C\# sebagai bahasa yang digunakan untuk mengembangkan game nya.

Unity mendukung pembuatan game $2 \mathrm{D}$ dan $3 \mathrm{D}$, namun lebih ditekankan pada 3D. Pengembangan game lebih ditekankan pada desain dan tampilan visual daripada pemrograman.

Unity memiliki jendela-jendela, dimana setiap jendela memiliki fungsi yang berbeda-beda. Pengguna dapat menampilkan, menyembunyikan, merubah ukuran dan mengatur tata letak dari sebuah jendela.

Berikut ini merupakan jendela-jendela yang terdapat pada Unity :

1. Window Animation, jendela ini dapat digunakan ketika pengguna akan membuat animasi sederhana untuk permainan yang dibuat.

2. Window Hierarchi, Jendela Hirarki berhubungan dengan jendela Scene. Jendela hirarki akan menampilkan apa yang ada di dalam jendela Scene dalam bentuk daftar.

3. Window Inspector, Jendela ini menyediakan berbagai pengaturan. Isi dari jendela ini dapat berubah-ubah ketika mengklik objek yang berbeda.

4. Window Project, Jendela ini terdapat hirarki dan folderfolder aset yang dimiliki. Aset dapat digunakan dengan melakukan drag drop ke jendela Scene.

5. Window Game, Jendela Permainan merupakan jendela simulasi permainan ketika dijalankan. Jendela ini banyak berfungsi pada proses debugging ketika menjalankan permainan.

6. Window Scene, Jendela Adegan digunakan untuk mengatur tata letak dari suatu objek dalam permainan. Pengguna dapat memasukkan objek dengan melakukan drag drop dari jendela Proyek ke dalam jendela ini. 
F. Metodologi Pengembangan Mutimedia

Metodologi yang digunakan adalah Multimedia Development Life Cycle (MDLC) yang bersumber dari Luther (1994) dan sudah dimodifikasi oleh Sutopo. Metodologi pengembangan multimedia tersebut terdiri dari enam tahap, yaitu konsep (concept), perancangan (design), pengumpulan materi (material collecting), pembuatan (assembly), pengujian (testing), dan distribusi (distribution). Keenam tahap ini tidak harus berurutan dalam prakteknya, tahap-tahap tersebut dapat saling bertukar posisi ${ }^{[13]}$. Meskipun begitu, tahap konsep memang harus menjadi hal yang pertama kali dikerjakan.

Metodologi pengembangan multimedia Luther yang sudah dimodifikasi oleh Sutopo ditunjukkan pada Gambar 2.

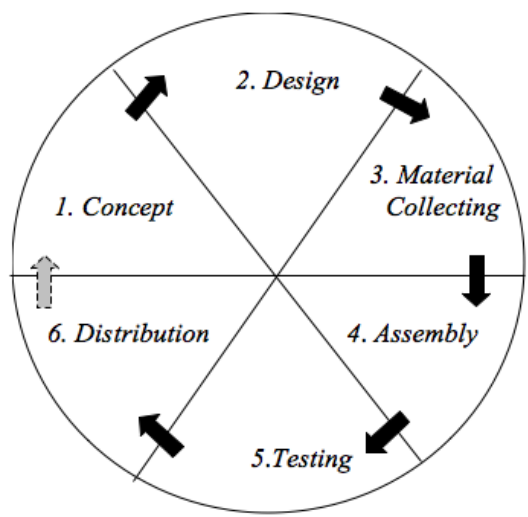

Gambar 2. Tahapan pengembangan multimedia ${ }^{[12]}$

\section{G. Metode Pengumpulan Data}

Angket / kuesioner adalah kumpulan dari pertanyaan yang diajukan secara tertulis dan digunakan untuk memperoleh informasi dari responden.

Dalam penelitian ini menggunakan skala likert. Skala likert adalah suatu skala yang umum digunakan dalam kuesioner, dan merupakan skala paling banyak digunakan dalam riset berupa survei. Untuk menanggapi pertanyaan dalam skala likert, responden menentukan tingkat persetujuan mereka terhadap suatu pertanyaan dengan memilih salah satu dari pilihan yang tersedia. Metode pengujian aplikasi yang digunakan adalah metode Black Box Testing dan Betha Testing.

\section{PERANCANGAN SISTEM}

A. Tahapan Pengembangan Multimedia

1. Konsep

Konsep dalam media pembelajaran pendamping yang dibuat adalah bagaimana menyajikan sebuah materi pembelajaran interaktif pendamping yang dapat mempermudah siswa dan guru. Pembelajaran interaktif ini bertujuan untuk menarik minat belajar para siswa agar dapat dengan mudah menerima materi serta dapat belajar secara mandiri kapanpun dan dimanapun. Bagi guru, dengan adanya media pembelajaran berbasis mobile ini maka guru tidak harus lagi menjelaskan materi secara mendetail dengan cara yang konvensional, artinya guru hanya menjadi fasilitator ketika ada materi yang belum paham saja. Materi yang disajikan dalam media pembelajaran berbasis mobile ini adalah materi tentang budaya Indonesia yang meliputi rumah adat, pakaian adat dan alat musik tradisional.

\section{Desain}

Aplikasi yang dibuat mempunyai 4 menu utama yaitu menu Mulai, menu Yuk Bermain !, menu Tentang Saya, dan Menu Bantuan. Pada halaman menu utama ini ditampilkan semua menu-menu yang ada beserta tombol pengaturan audio dan keluar. Alur aplikasi digambarkan dengan diagram alir. Diagram alir menu awal ditunjukkan oleh Gambar 3.

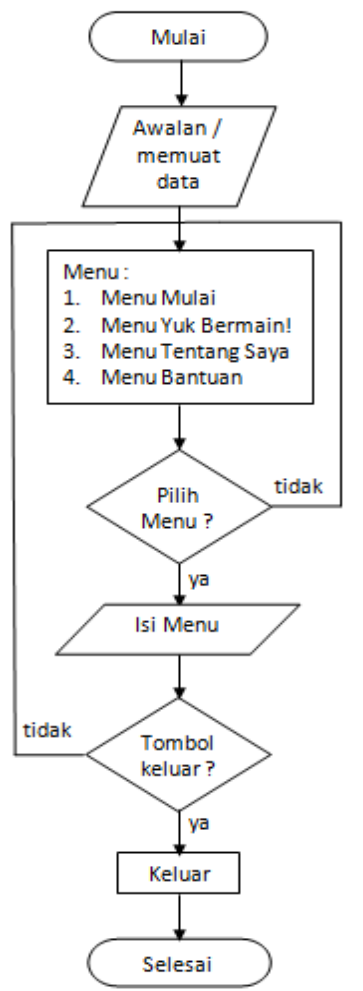

Gambar 3. Diagram alir menu awal

Bagan alir pada menu Mulai ditunjukkan oleh Gambar 4. 


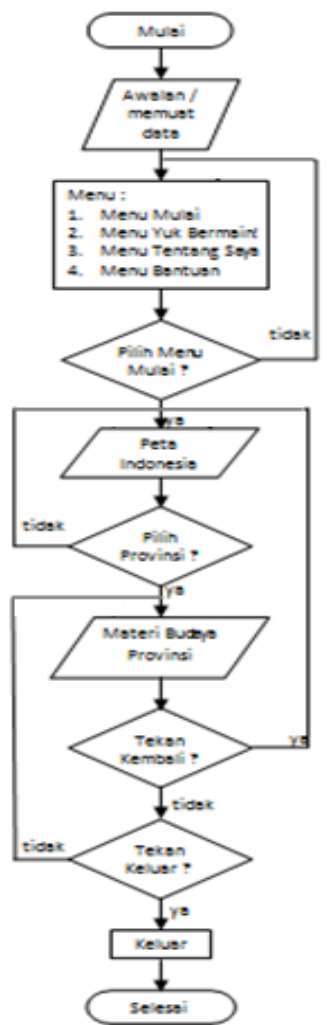

Gambar 4. Diagram alir menu Mulai

Diagram alir menu Yuk Bermain ! ditunjukkan oleh Gambar 5 .

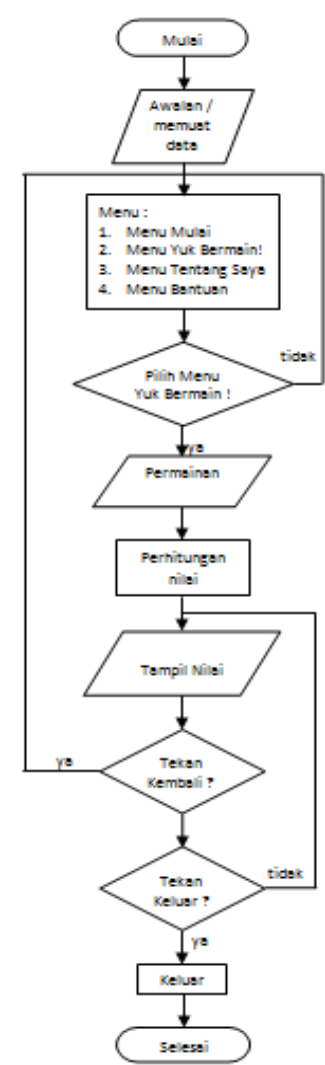

Gambar 5. Diagram alir menu Yuk Bermain !

Diagram alir untuk menu Tentang Saya ditunjukkan oleh Gambar 6.

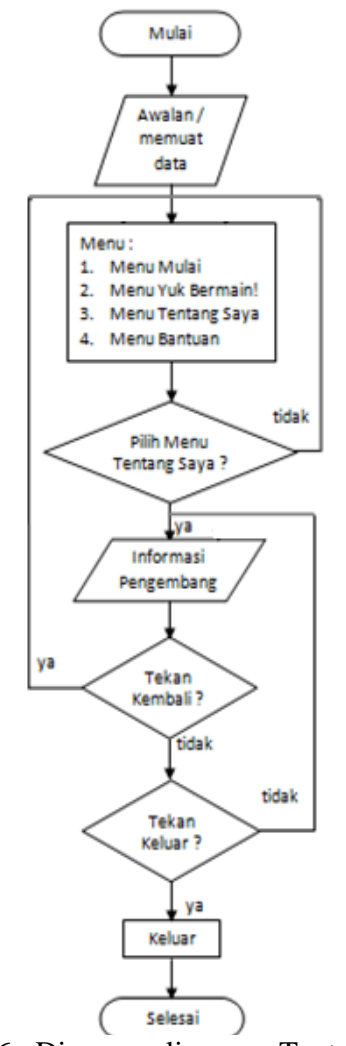

Gambar 6. Diagram alir menu Tentang Saya

7.

Diagram alir menu Bantuan ditunjukkan oleh Gambar

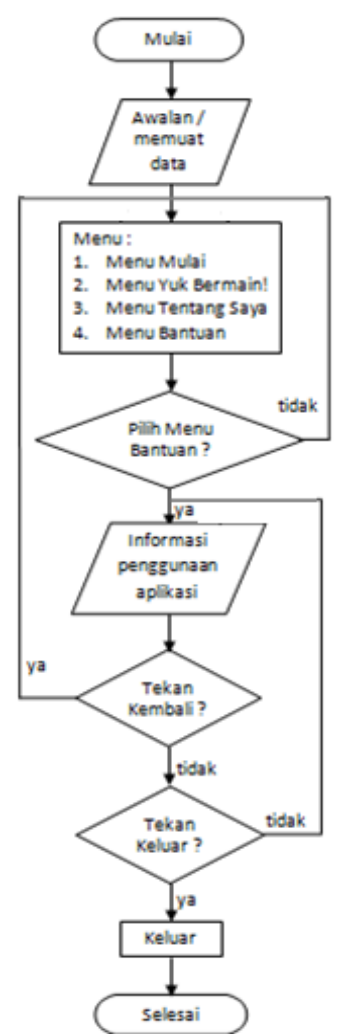

Gambar 7. Diagram alir menu Bantuan

Setelah dibuat diagram alir untuk mengetahui alur program, selanjutnya dibuat desain tampilan aplikasi. Tampilan menu awal ditunjukkan oleh Gambar 8. 


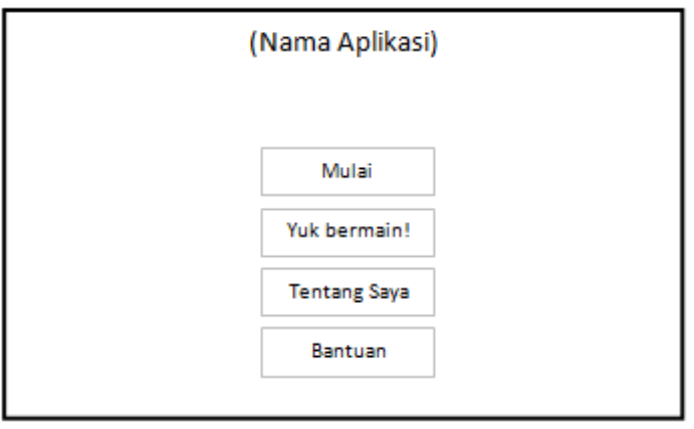

Gambar 8. Tampilan menu awal

Tampilan menu Mulai ketika ditekan ditunjukkan oleh Gambar 9.

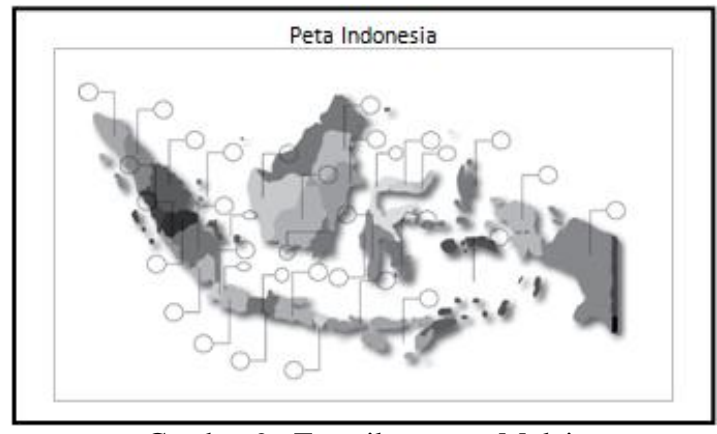

Gambar 9. Tampilan menu Mulai

Tampilan materi ketika salah satu tombol nama provinsi ditekan ditunjukkan oleh Gambar 10.

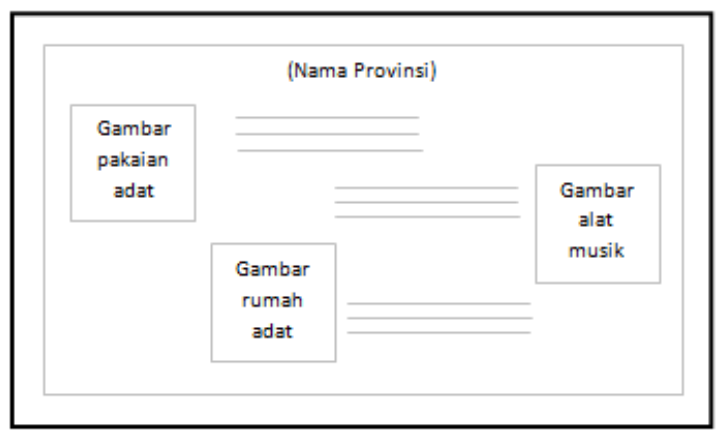

Gambar 10.Tampilan materi pada salah satu provinsi

Tampilan menu Yuk Bermain ! ditunjukkan oleh Gambar 11.

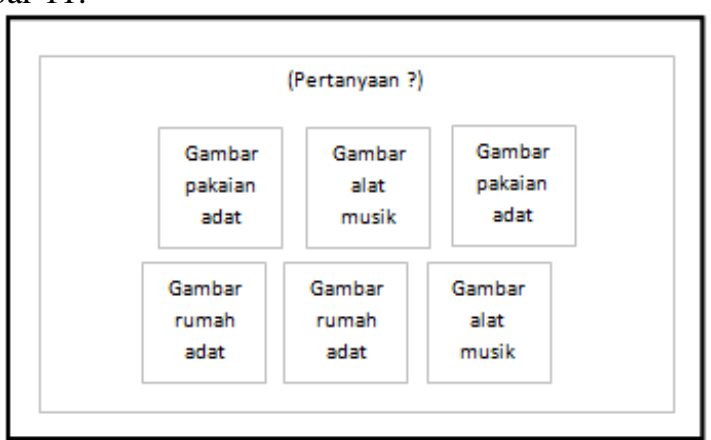

Gambar 11.Tampilan menu permainan teka-teki silang

Tampilan nilai permainan tebak gambar ditunjukkan oleh Gambar 12.

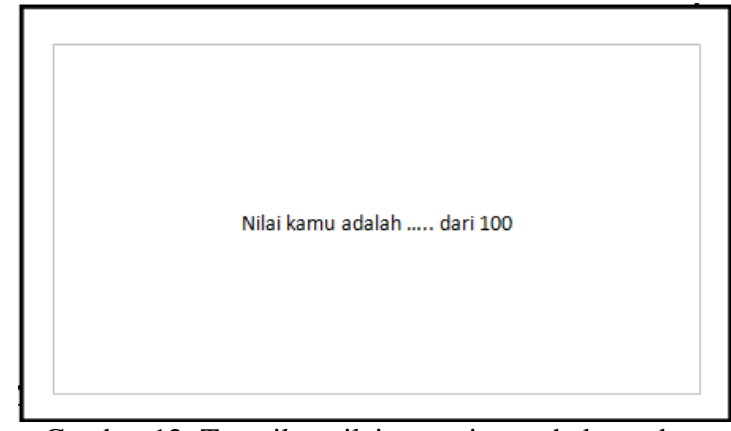

Gambar 12. Tampilan nilai permainan tebak gambar

Tampilan menu Tentang Saya ditunjukkan oleh Gambar 13.

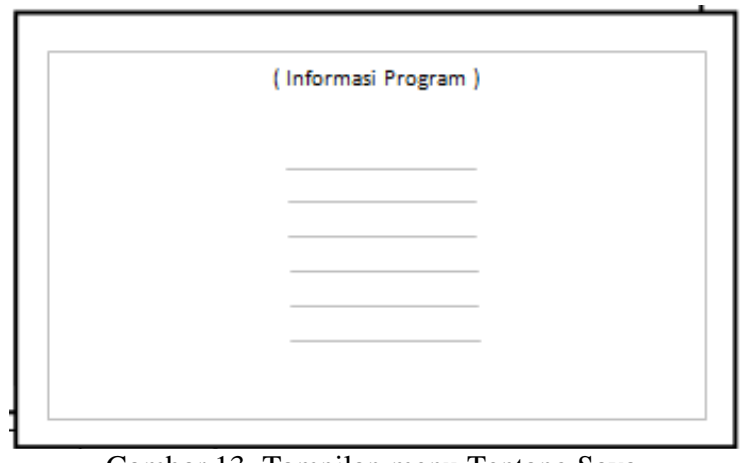

Gambar 13. Tampilan menu Tentang Saya

Tampilan menu Bantuan ditunjukkan oleh Gambar 14.

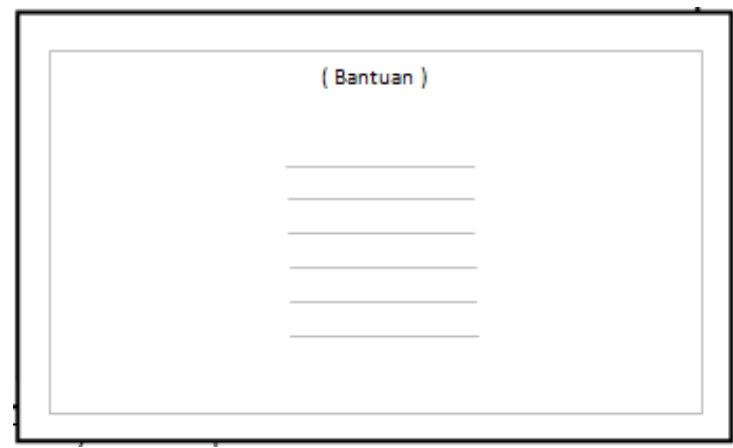

Gambar 14. Tampilan menu Bantuan

\section{Pengumpulan Materi}

Tahap pengumpulan materi Budaya dilakukan sebagai bahasan pada aplikasi yang dibuat. Materi Budaya didapat dari berbagai sumber, salah satunya adalah buku bahan ajar materi budaya di Sekolah Dasar. Selain itu, pengumpulan gambar, audio maupun video sumber yang digunakan sebagai bahan pembuatan aplikasi pembelajaran didapat dari internet.

4. Pembuatan

Alat dan bahan yang digunakan dalam pembuatan multimedia pembelajaran ini adalah sebagai berikut.

a. Perangkat keras

1) PC (Personal Computer) atau Laptop

2) Smartphone Android

3) Angket (Kuisioner)

b. Perangkat lunak

1) Microsoft Windows 8

2) Unity Engine 5 
3) Adobe Illustrator

4) Adobe PhotoShop

5) BlueStacks

\section{Pengujian}

Pengujian aplikasi dilakukan untuk mengetahui apakah aplikasi yang dibuat sudah sesuai dengan perancangan dan kebutuhan atau belum. Pengujian dilakukan pada tiap menu sebelum aplikasi selesai secara keseluruhan. Hal ini bertujuan agar apabila terdapat kesalahan fungsinya akan langsung dapat diperbaiki. Pengujian pada pembuatan aplikasi ini menggunakan pengujian kotak hitam. Setelah tahap pengujian ini selesai dan aplikasi sudah selesai maka dilanjutkan pada tahap terakhir yaitu distribusi.

\section{Distribusi}

Tahap distribusi aplikasi ini dilakukan oleh smartphone melalui pengiriman langsung dengan Bluetooth atau kabel data ke smartphone guru atau siswa Sekolah Dasar.

\section{B. Langkah-langkah Penelitian}

\section{Perencanaan}

Penelitian ini berencana agar aplikasi multimedia yang sudah dibuat akan diimplementasikan kepada tenaga pengajar atau guru dan siswa Sekolah Dasar sebagai aplikasi multimedia pembelajaran pendamping.

2. Pelaksanaan

Tahap pelaksanaan dilakukan dengan mengimplementasikan Aplikasi Multimedia Pembelajaran pendamping berbasis mobile di salah satu Sekolah Dasar untuk mata pelajaran Ilmu Pengetahuan Sosial (IPS) materi Budaya.

3. Pengamatan

Tahap pengamatan dilakukan untuk mengamati perilaku siswa ketika menggunakan aplikasi. sekaligus mengamati motivasi belajar dan pemahaman siswa pada materi yang telah dikemas dalam aplikasi.

Data atau hasil dari tahapan ini dapat diperoleh dari angket yang dibagikan kepada siswa untuk kemudian diberi penilaian oleh siswa mengenai aplikasi yang telah dicoba. Dalam angket berisi pertanyaan-pertanyaan tentang hasil aplikasi.

4. Analisis

Data didapat dari hasil penilaian dari angket yang dibagikan kepada siswa. Angket yang telah dibagikan bertujuan sebagai media pengujian aplikasi oleh responden dan mengetahui minat serta motivasi belajar siswa dalam pembelajaran menggunakan aplikasi multimedia pembelajaran pendamping berbasis mobile ini.

\section{Metode Pengumpulan Data}

Metode pengumpulan data yang digunakan dalam penelitian ini dengan menggunakan angket (kuesioner). Angket yang digunakan untuk mengumpulkan data dalam penelitian ini meliputi angket Black Box Testing dan Betha Testing. Pada penelitian ini aplikasi media pembelajaran akan diperbaiki jika $75 \%$ jawaban responden angket Black Box Testing merupakan jawaban negatif atau $75 \%$ jawaban kuisioner berisi jawaban yang menyatakan Tidak Setuju (TS) dan Kurang Setuju (KS), dan jika lebih dari $75 \%$ jawaban dari responden angket Black Box Testing merupakan jawaban positif, artinya jawaban kuesioner $75 \%$ menyatakan Setuju (S) dan Sangat Setuju (SS) maka kegiatan penelitian dilanjutkan dan analisa hasil penelitian menggunakan angket Betha Testing.

\section{Teknik Analisis Data}

Data yang diperoleh selanjutnya dianalisis untuk didapatkan suatu kesimpulan. Dalam penelitian ini menggunakan analisis deskriptif. Data yang dikumpulkan tersebut perlu disajikan supaya mudah dimengerti, menarik, komunikatif dan informatif bagi pihak lain. Teknik yang dapat digunakan seperti bentuk tabel dan grafik.

Penelitian ini dikatakan berhasil apabila dari angket diperoleh hasil yang berada pada rentang $76 \% \leq$ skor $\leq 100 \%$ $=$ Baik atau pada kriteria $51 \% \leq$ skor $\leq 75 \%=$ Cukup Baik. Jika penelitian sudah berhasil maka media pembelajaran interaktif dapat digunakan oleh guru atau siswa sebagai alternatif pembelajaran yang menyenangkan di sekolah maupun diluar sekolah.

\section{Hasil PENELITIAN DAN PEMBAHASAN}

\section{A. HASIL PENELITIAN}

Berikut merupakan tampilan aplikasi yang dibuat.

\section{Halaman utama aplikasi}

Aplikasi pertama kali akan menampilkan halaman utama dengan 4 tombol menu. Terdapat 4 tombol menu utama yang meliputi :
a. Menu Mulai
b. Menu Yuk Bermain !
c. Menu Tentang Saya
d. Menu Bantuan

beserta tombol keluar dan pengaturan suara. Tampilan awal aplikasi ditunjukkan oleh Gambar 15.

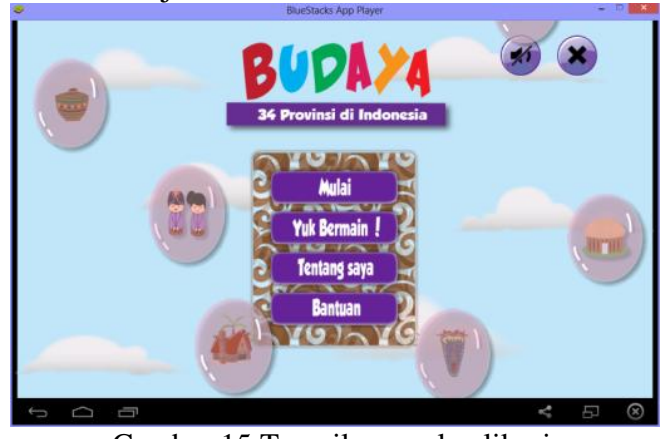

Gambar 15.Tampilan awal aplikasi

\section{Tampilan menu Mulai}

Aplikasi ini memiliki menu Mulai yang merupakan menu terpenting dalam aplikasi ini. Apabila menu Mulai dipilih, maka akan menampilkan peta Indonesia beserta 34 nama provinsi yang terdapat di Indonesia. Nama provinsi yang terdapat pada peta dapat dipilih (ditekan) untuk melihat materi budaya mengenai provinsi tersebut. Tampilan menu Mulai apabila ditekan, ditunjukkan oleh Gambar 16. 


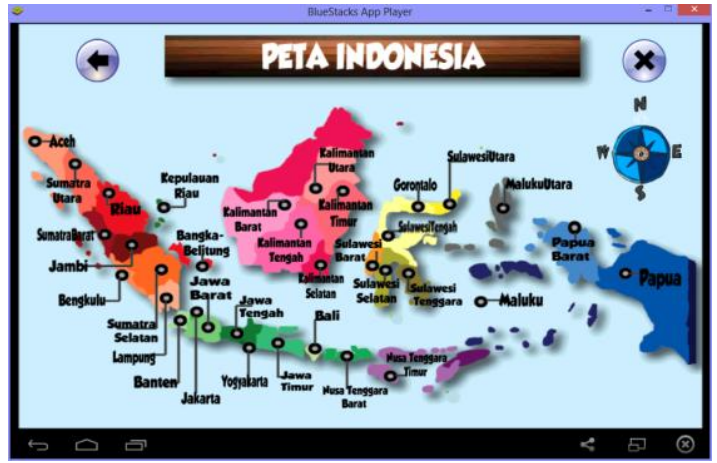

Gambar 16.Tampilan menu Mulai

3. Tampilan materi setiap provinsi

Materi budaya yang ditampilkan pada setiap provinsi meliputi rumah adat, alat musik tradisional dan pakaian adat. Materi tersebut dijelaskan secara singkat dan dilengkapi dengan gambar. Tampilan salah satu materi apabila tombol provinsi ditekan, ditunjukkan oleh Gambar 17

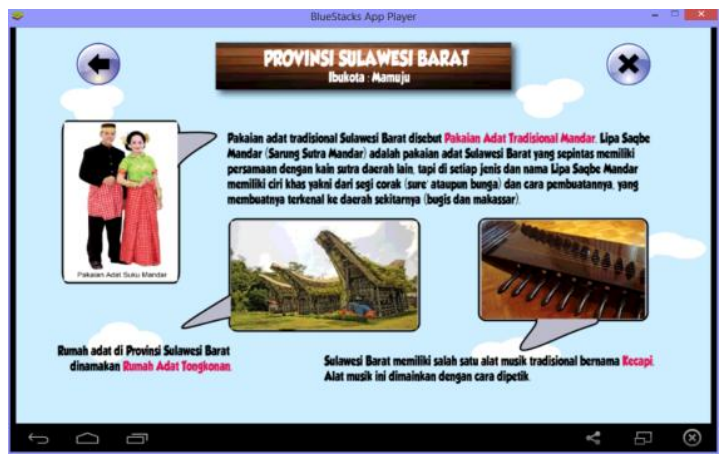

Gambar 17.Tampilan materi

4. Tampilan menu Yuk Bermain !

Menu Yuk Bermain ! pada aplikasi ini berisi permainan menebak gambar budaya apa saja yang terdapat pada sebuah provinsi sesuai dengan permintaan yang tertera. Permainan ini bertujuan untuk melatih daya ingat terhadap materi yang telah disajikan pada aplikasi. Terdapat 10 soal yang harus dijawab untuk dapat melihat nilai hasil tebakan. Disediakan 5 buah gambar dan gambar yang ditebak akan menampilkan teks nama budaya tersebut dengan ketentuan berwarna hijau apabila benar atau merah apabila salah. Pengguna hanya diberi kesempatan sebanyak 3 kali untuk menebak gambar. Apabila kesempatan telah habis, maka akan menampilkan halaman permintaan selanjutnya. Tampilan menu Yuk Bermain apabila ditekan, ditunjukkan oleh Gambar 18.

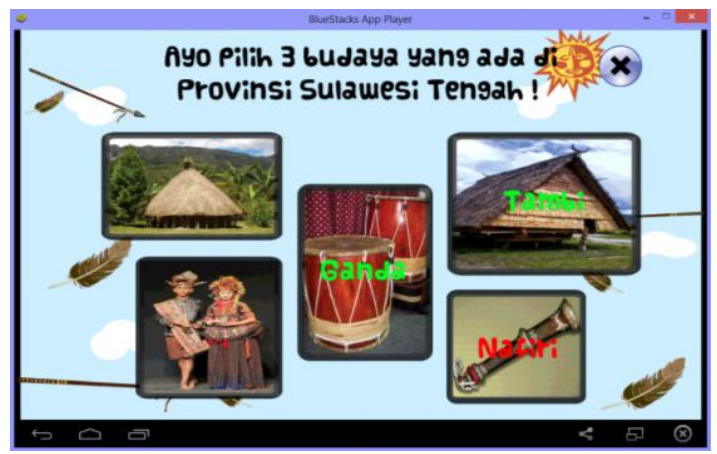

Gambar 18.Tampilan menu Yuk Bermain!
Setelah selesai menjawab semua soal, maka akan ditampilkan nilai hasil dari menebak gambar. Nilai tertinggi adalah 100 sedangkan nilai terendah adalah 0 . Tampilan nilai permainan ditunjukkan oleh Gambar 19.

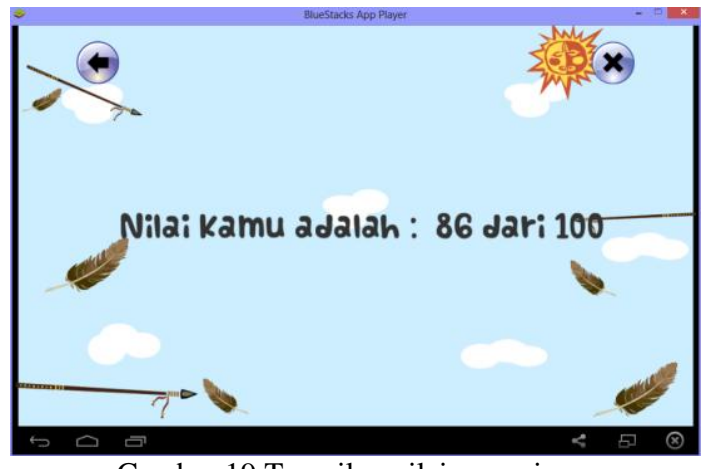

Gambar 19.Tampilan nilai permainan

5. Tampilan menu Tentang Saya

Menu Tentang Saya pada aplikasi ini berisi mengenai informasi yang berkaitan dengan pembuatan aplikasi multimedia pembelajaran ini. Tampilan menu Tentang Saya apabila ditekan, ditunjukkan oleh Gambar 20.

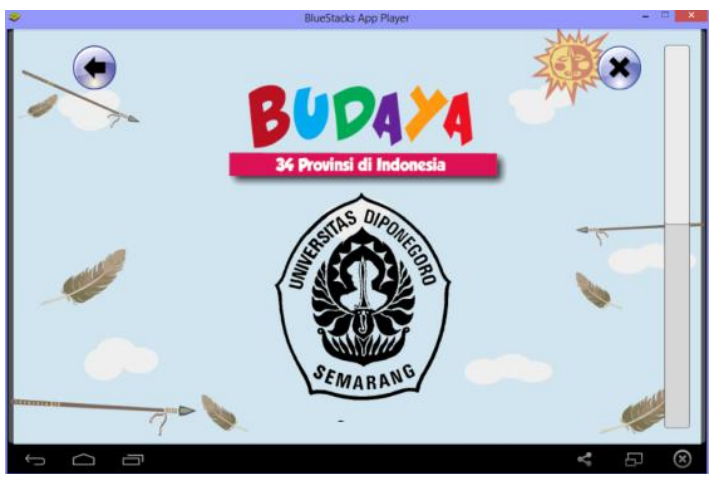

Gambar 20.Tampilan menu Tentang Saya

6. Tampilan menu Bantuan

Menu Bantuan pada aplikasi ini berisi mengenai informasi dan kegunaan dari tiap menu yang disediakan di halaman utama. Tampilan menu Bantuan apabila ditekan, ditunjukkan oleh Gambar 21.

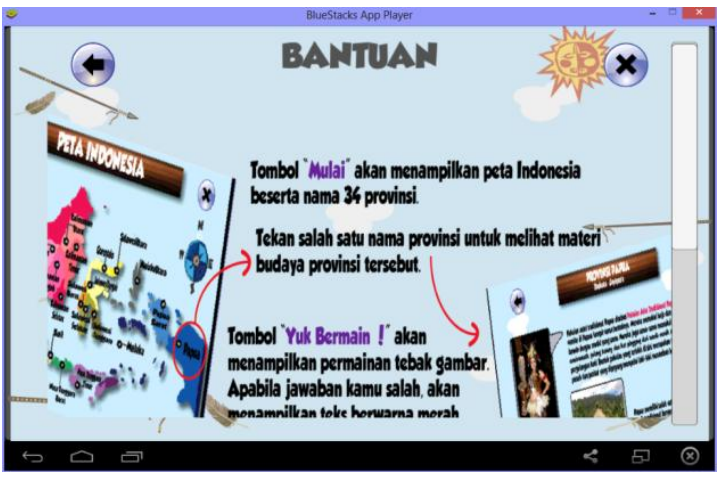

Gambar 21.Tampilan menu Bantuan

B. Pengujian aplikasi menggunakan metode Uji Kotak Hitam Pengujian aplikasi multimedia pembelajaran interaktif ini dilakukan dengan menggunakan metode uji kotak hitam. 
Pengujian ini dilakukan untuk menunjukkan fungsi program yang dibuat tentang cara operasi dan kegunaannya, apakah keluaran data sesuai dengan yang diharapkan. Pengujian ini dilakukan untuk mengetahui apakah masih terjadi kesalahan program atau program sudah berhasil diselesaikan dengan benar.

Pengujian aplikasi dibuat berupa tabel pengujian kotak hitam dari menu yang ada dalam aplikasi. Tabel pengujian pada aplikasi secara keseluruhan ditunjukkan oleh Tabel 1

Tabel 1. Tabel pengujian aplikasi secara keseluruhan

\begin{tabular}{|c|c|c|c|}
\hline $\begin{array}{c}\text { Nama } \\
\text { Pengujian }\end{array}$ & $\begin{array}{c}\text { Bentuk } \\
\text { Pengujian }\end{array}$ & $\begin{array}{c}\text { Hasil yang } \\
\text { Diharapkan }\end{array}$ & $\begin{array}{c}\text { Hasil } \\
\text { Pengujian }\end{array}$ \\
\hline $\begin{array}{l}\text { Loading } \\
\text { (memuat } \\
\text { data) }\end{array}$ & $\begin{array}{l}\text { Membuka } \\
\text { aplikasi }\end{array}$ & $\begin{array}{l}\text { Tampilan } \\
\text { halaman } \\
\text { utama }\end{array}$ & Berhasil \\
\hline $\begin{array}{l}\text { Pengujian } \\
\text { menu Mulai }\end{array}$ & $\begin{array}{l}\text { Mengklik } \\
\text { tombol Mulai }\end{array}$ & $\begin{array}{l}\text { Tampil Peta } \\
\text { Indonesia } \\
\text { beserta tombol } \\
34 \text { nama } \\
\text { provinsi }\end{array}$ & Berhasil \\
\hline $\begin{array}{l}\text { Pengujian } \\
\text { tombol nama } \\
\text { provinsi }\end{array}$ & $\begin{array}{l}\text { Mengklik } \\
\text { tombol nama } \\
\text { provinsi }\end{array}$ & $\begin{array}{l}\text { Tampil materi } \\
\text { budaya } \\
\text { provinsi }\end{array}$ & Berhasil \\
\hline $\begin{array}{l}\text { Pengujian } \\
\text { menu Yuk } \\
\text { Bermain! }\end{array}$ & $\begin{array}{l}\text { Mengklik } \\
\text { tombol Yuk } \\
\text { Bermain! }\end{array}$ & $\begin{array}{l}\text { Tampil } \\
\text { pertanyaan } \\
\text { berturut-turut } \\
\text { sejumlah } 10 \\
\text { soal }\end{array}$ & Berhasil \\
\hline $\begin{array}{l}\text { Pengujian } \\
\text { memilih } \\
\text { gambar pada } \\
\text { menu Yuk } \\
\text { Bermain! }\end{array}$ & $\begin{array}{l}\text { Mengklik } \\
\text { gambar }\end{array}$ & $\begin{array}{l}\text { Tampil nama } \\
\text { gambar } \\
\text { beserta warna } \\
\text { teks (merah } \\
\text { jika salah / } \\
\text { hijau jika } \\
\text { benar) }\end{array}$ & Berhasil \\
\hline $\begin{array}{l}\text { Pengujian } \\
\text { perhitungan } \\
\text { nilai tebak } \\
\text { gambar pada } \\
\text { menu Yuk } \\
\text { Bermain! }\end{array}$ & $\begin{array}{l}\text { Menyelesaikan } \\
\text { semua soal } \\
\text { pada } \\
\text { permainan }\end{array}$ & $\begin{array}{l}\text { Tampil nilai } \\
\text { perhitungan }\end{array}$ & Berhasil \\
\hline $\begin{array}{l}\text { Pengujian } \\
\text { menu } \\
\text { Tentang Saya }\end{array}$ & $\begin{array}{l}\text { Mengklik } \\
\text { menu Tentang } \\
\text { Saya }\end{array}$ & $\begin{array}{l}\text { Tampil } \\
\text { informasi } \\
\text { yang berkaitan } \\
\text { dengan } \\
\text { pembuatan } \\
\text { aplikasi }\end{array}$ & Berhasil \\
\hline $\begin{array}{l}\text { Pengujian } \\
\text { tombol } \\
\text { kembali } \\
\text { (tombol } \\
\text { panah) } \\
\end{array}$ & $\begin{array}{l}\text { Mengklik } \\
\text { tombol kembali }\end{array}$ & $\begin{array}{l}\text { Tampilan } \\
\text { kembali ke } \\
\text { halaman } \\
\text { sebelumnya }\end{array}$ & Berhasil \\
\hline $\begin{array}{l}\text { Pengujian } \\
\text { tombol } \\
\text { pengaturan } \\
\text { suara (tombol } \\
\text { sound) }\end{array}$ & $\begin{array}{l}\text { Mengklik } \\
\text { tombol } \\
\text { pengaturan } \\
\text { suara }\end{array}$ & $\begin{array}{l}\text { Membesarkan } \\
\text { dan / } \\
\text { mengecilkan } \\
\text { suara musik } \\
\text { latar belakang }\end{array}$ & Berhasil \\
\hline $\begin{array}{l}\text { Pengujian } \\
\text { tombol keluar } \\
\text { (tombol } \\
\text { silang) }\end{array}$ & $\begin{array}{l}\text { Mengklik } \\
\text { tombol keluar }\end{array}$ & $\begin{array}{l}\text { Muncul } \\
\text { pertanyaan } \\
\text { konfirmasi }\end{array}$ & Berhasil \\
\hline $\begin{array}{l}\text { Pengujian } \\
\text { tombol "Ya" } \\
\text { pada }\end{array}$ & $\begin{array}{l}\text { Mengklik } \\
\text { tombol "Ya" }\end{array}$ & $\begin{array}{l}\text { Menutup } \\
\text { aplikasi }\end{array}$ & Berhasil \\
\hline
\end{tabular}

\begin{tabular}{|l|l|l|l|}
\hline $\begin{array}{l}\text { pertanyaan } \\
\text { konfirmasi }\end{array}$ & & & \\
\hline $\begin{array}{l}\text { Pengujian } \\
\text { tombol } \\
\text { "Tidak" pada } \\
\text { pertanyaan } \\
\text { konfirmasi }\end{array}$ & $\begin{array}{l}\text { Mengklik } \\
\text { tombol "Tidak" }\end{array}$ & $\begin{array}{l}\text { Menutup } \\
\text { pertanyaan }\end{array}$ & \\
& & $\begin{array}{l}\text { konfirmasi } \\
\text { dan }\end{array}$ & Belanjutkan \\
aktifitas & Berhasil \\
program & \\
\hline
\end{tabular}

C. Analisis hasil pengujian aplikasi menggunakan kuesioner Pengujian aplikasi ini ditargetkan kepada siswa sekolah dasar kelas V. Kegiatan pengujian aplikasi ini dilakukan dengan cara mendemokan aplikasi di depan siswa dan memberi kesempatan siswa satu per satu untuk mencoba aplikasi tersebut. Selain itu, siswa juga dapat memasang aplikasi ini di ponsel pribadi. Setelah semua siswa jelas dan selesai mencoba aplikasinya, siswa diberikan kuesioner berisi pertanyaan yang berkaitan dengan aplikasi yang telah dijelaskan. Terdapat sejumlah 20 kuesioner yang dibagikan kepada siswa / responden. Kemudian kuesioner yang telah diisi, digunakan untuk mendapatkan data dari responden tentang aplikasi yang dibuat. Kuesioner yang dibagikan berisi 15 pertanyaan yang disusun menjadi 1. Namun dalam pembahasan dibawah ini, 15 pertanyaan pada kuesioner dikelompokkan menjadi 3 tema dan disajikan dalam 3 tabel yang berbeda. Data pada angket yang didapat, kemudian diolah dan disajikan dalam bentuk tabel dan diagram batang agar mudah dibaca.

Berikut tabel dan diagram batang hasil data kuesioner yang sudah diolah.

1. Tampilan Program

Tabel 2. Hasil data kuesioner tampilan program

\begin{tabular}{|c|l|c|c|}
\hline No. & \multicolumn{1}{|c|}{ Pertanyaan } & Nilai & Keterangan \\
\hline $\mathbf{1}$ & $\begin{array}{l}\text { Apakah tampilan awal } \\
\text { program menarik ? }\end{array}$ & 85 & Baik \\
\hline $\mathbf{2}$ & $\begin{array}{l}\text { Apakah program memiliki } \\
\text { tampilan warna yang } \\
\text { menarik? }\end{array}$ & 90 & Baik \\
\hline $\mathbf{3}$ & $\begin{array}{l}\text { Apakah teks yang } \\
\text { ditampilkan mudah dibaca } \\
\text { ? }\end{array}$ & 86,25 & Baik \\
\hline $\mathbf{4}$ & $\begin{array}{l}\text { Apakah gambar yang } \\
\text { ditampilkan mampu } \\
\text { memperjelas materi ? }\end{array}$ & 83,75 & Baik \\
\hline $\mathbf{5}$ & $\begin{array}{l}\text { Apakah permainan yang } \\
\text { ditampilkan menarik ? }\end{array}$ & 92,5 & Baik \\
\hline \multicolumn{2}{|c|}{ Rata-rata } & 87,5 & Baik \\
\hline
\end{tabular}

22

Diagram batang dari Tabel 2 ditunjukkan oleh Gambar

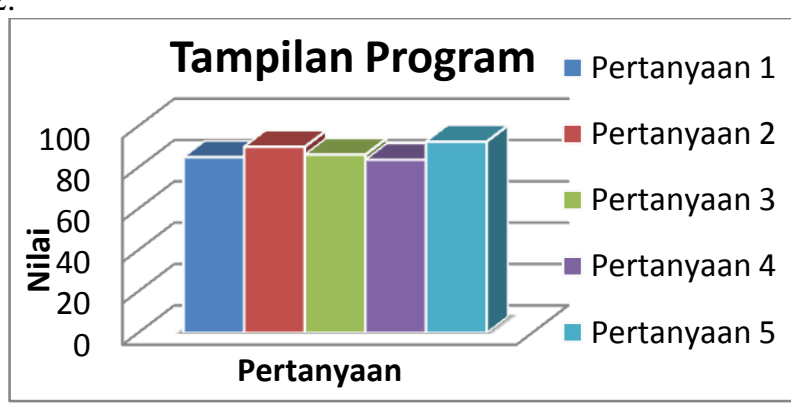

Gambar 22.Diagram batang dari tabel 2 
Dari hasil olah data kuesioner tentang tampilan program didapatkan nilai rata-rata 87,5 atau dapat disimpulkan bahwa tampilan program dari aplikasi yang dibuat berhasil dengan kategori Baik.

2. Kesesuaian Program Bahan Ajar

Tabel 3. Hasil data kuesioner kesesuaian program bahan ajar

\begin{tabular}{|c|l|c|c|}
\hline No & \multicolumn{1}{|c|}{ Pertanyaan } & Nilai & Keterangan \\
\hline $\mathbf{1}$ & $\begin{array}{l}\text { Apakah materi berkaitan dengan } \\
\text { mata pelajaran yang diberikan } \\
\text { oleh guru ? }\end{array}$ & 87,5 & Baik \\
\hline $\mathbf{2}$ & $\begin{array}{l}\text { Apakah program bantu belajar } \\
\text { IPS ini dapat meningkatkan } \\
\text { semangat belajar secara mandiri } \\
\text { ? }\end{array}$ & 87,5 & Baik \\
\hline $\mathbf{3}$ & $\begin{array}{l}\text { Apakah permainan dalam } \\
\text { program sesuai dengan materi } \\
\text { yang dibahas? }\end{array}$ & 90 & Baik \\
\hline $\mathbf{4}$ & $\begin{array}{l}\text { Apakah program bantu belajar } \\
\text { IPS dapat memberikan } \\
\text { gambaran materi Budaya di } \\
\text { Indonesia? }\end{array}$ & 93,75 & Baik \\
\hline $\mathbf{5}$ & $\begin{array}{l}\text { Apakah materi mudah dipahami } \\
\text { ? }\end{array}$ & 88,75 & Baik \\
\hline \multicolumn{2}{|c|}{ Rata-rata } & 89,5 & Baik \\
\hline
\end{tabular}

Diagram batang hasil data kuesioner tentang kesesuaiaan program bahan ajar ditunjukkan oleh Gambar 23.

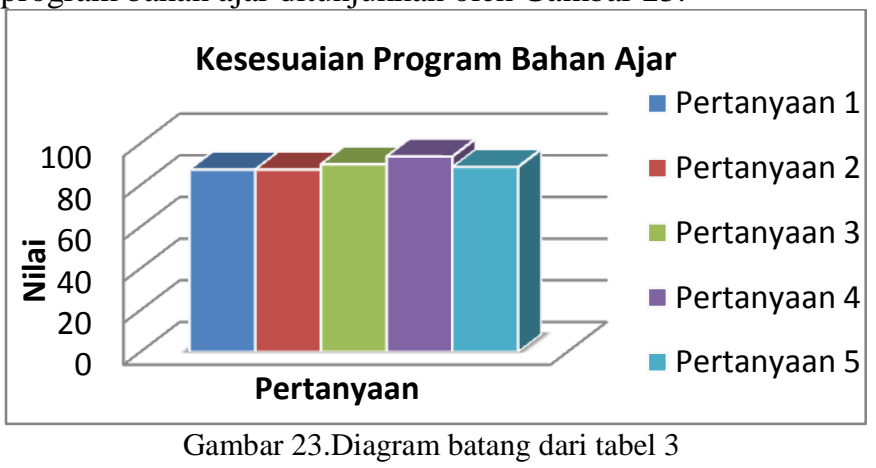

Dari hasil olah data kuesioner tentang kesesuaian program bahan ajar didapatkan nilai rata-rata 89,5 atau dapat disimpulkan bahwa aplikasi yang dibuat berisi materi yang sesuai dengan pelajaran yang diberikan oleh guru kepada siswa SD .

3. Perancangan media terhadap aspek kemudahan pengguna

Tabel 4. Hasil data kuesioner perancangan media terhadap aspek kemudahan pengguna

\begin{tabular}{|c|l|c|c|}
\hline No & \multicolumn{1}{|c|}{ Pertanyaan } & Nilai & $\begin{array}{c}\text { Ketera } \\
\text { ngan }\end{array}$ \\
\hline $\mathbf{1}$ & Apakah program mudah digunakan ? & 91,25 & Baik \\
\hline $\mathbf{2}$ & $\begin{array}{l}\text { Apakah menu bantuan yang telah } \\
\text { disediakan bermanfaat ? }\end{array}$ & 88,75 & Baik \\
\hline $\mathbf{3}$ & $\begin{array}{l}\text { Apakah menu yang ada dapat } \\
\text { digunakan dengan mudah ? }\end{array}$ & 82,5 & Baik \\
\hline $\mathbf{4}$ & $\begin{array}{l}\text { Apakah semua tombol pada program } \\
\text { dapat berfungsi dengan baik ? }\end{array}$ & 81,25 & Baik \\
\hline $\mathbf{5}$ & $\begin{array}{l}\text { Apakah program bantu belajar IPS } \\
\text { ini akan dapat dengan mudah } \\
\text { digunakan kapan saja dan dimana } \\
\text { saja? }\end{array}$ & 93,75 & Baik \\
\hline \multicolumn{2}{|c|}{ Rata-rata } & 87,5 & Baik \\
\hline
\end{tabular}

Diagram batang hasil data kuesioner tentang perancangan media terhadap aspek kemudahan pengguna ditunjukkan oleh Gambar 24.

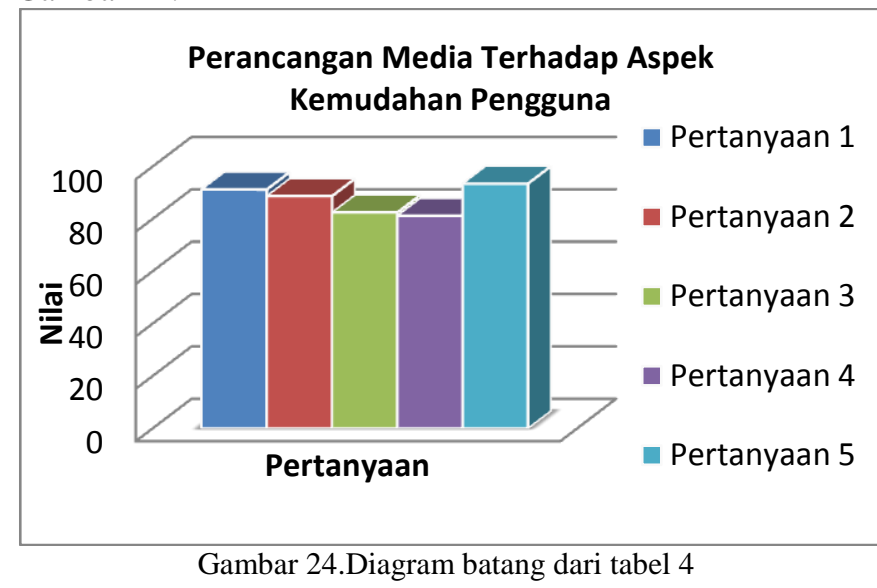

Dari hasil olah data kuesioner tentang perancangan media terhadap aspek kemudahan pengguna didapatkan nilai ratarata 87,5 atau dapat disimpulkan bahwa perancangan aplikasi terhadap aspek kemudahan pengguna dalam menggunakan aplikasi sudah Baik.

Berdasarkan hasil olah data kuesioner didapat nilai ratarata tampilan program sebesar 87,5 atau dapat disimpulkan dalam kategori Baik, nilai rata-rata tentang kesesuaian program bahan ajar sebesar 89,5 atau dapat disimpulkan dalam kategori Baik dan nilai rata-rata tentang perancangan media terhadap aspek kemudahan pengguna sebesar 87,5 atau dapat disimpulkan dalam kategori Baik. Nilai rata-rata dari semua hasil pertanyaan yang terdapat pada kuesioner adalah 88,16 . Lebih dari $75 \%$ jawaban kuesioner berisi jawaban positif dari responden, atau dapat dikatakan aplikasi yang dibuat sudah berhasil dengan baik. Keseluruhan dari hasil olah data kuesioner dapat disimpulkan bahwa aplikasi yang dibuat telah memenuhi syarat kelayakan yang sudah ditentukan sebelumnya dan dapat digunakan kepada siswa Sekolah Dasar untuk memanfaatkan media pendamping pembelajaran yang interaktif berbasis mobile ini dalam proses pembelajaran budaya sebagai alternatif pembelajaran yang menyenangkan.

\section{PENUTUP}

A. Kesimpulan

Kesimpulan dari penelitian Tugas Akhir ini diantaranya sebagai berikut.

1. Hasil uji Kotak Hitam (Black Box Testing) menunjukkan bahwa semua fungsi menu yang terdapat pada aplikasi telah berhasil sesuai dengan fungsinya.

2. Hasil olah data pada 20 kuesioner menunjukkan bahwa lebih dari $75 \%$ responden memberikan respon positif terhadap aplikasi, yang berarti juga lebih dari 75\% menjawab Setuju (S) atau Sangat Setuju (SS) pada pertanyaan yang diajukan dalam kuesioner. Nilai rata-rata yang didapatkan dari perhitungan jawaban kuesioner adalah 88,16 atau dapat disimpulkan dalam kategori "Baik". 
3. Aplikasi yang dibuat sudah berhasil dengan Baik, dan dapat digunakan oleh siswa di lingkungan sekolah maupun di luar sekolah untuk diterapkan sebagai media pendamping pembelajaran yang interaktif dan sebagai alternatif pembelajaran yang menyenangkan.

B. Saran

Saran yang dapat diberikan oleh penulis adalah sebagai berikut.

1. Aplikasi media pembelajaran yang dibuat hanya berisi materi budaya yang meliputi rumah adat, alat musik daerah dan pakaian adat, dan masih bisa dikembangkan dengan penambahan budaya yang lain, contohnya seperti senjata daerah atau bahasa daerah.

2. Peta Indonesia yang ditampilkan hanya bersifat statis sehingga tidak dapat diperbesar atau sebaliknya, diharapkan bisa dikembangkan agar dapat diperbesar atau sebaliknya.

3. Aplikasi media pendamping pembelajaran yang dibuat hanya memiliki permainan dengan soal yang hanya berjumlah 10 soal, diharapkan dapat dikembangkan dengan variasi permainan dan soal yang lebih banyak agar nantinya dapat menambah pemahaman terhadap budaya 34 provinsi di Indonesia.

\section{DAFTAR PUSTAKA}

[1] M. Aina, "Efektifitas Pemanfaatan Mutimedia Interaktif Pembelajaran IPA- BIOLOGI dalam Meningkatkan Motivasi Belajar Siswa Pria dan Wanita SMP 19 Kota Jambi," in Semirata FMIPA Universitas Lampung, Lampung, 2013.

[2] S. Nandi, "Penggunaan Multimedia Interaktif dalam Pembelajaran Geografi di Persekolahan," Jurnal "GEA" Jurusan Pendidikan Geografi, vol. 6, 2006.

[3] R. E. Mayer, Multimedia Learning, Yogyakarta : Pustaka Pelajar, 2009.

[4] d. J. Siregar, "Media Pembelajaran Berbasis Multimedia Mata Kuliah Design Publishing di STMIK Widya Pratama Pekalongan," Majalah Ilmiah IC Tech, Pekalongan, 2010.

[5] A. Arsyad, Media Pembelajaran, Jakarta: Rajawali Pers, 2009.

[6] I. ST, IPSL (Intisari Pengetahuan Sosial Lengkap) SD, Jakarta: Kawan Pustaka, 2004.

[7] Kementrian Pendidikan dan Kebudayaan, Sejarah Indonesia untuk SMA/MA Kelas XII, Jakarta: Kementrian Pendidikan dan Kebudayaan, 2015.

[8] E. Susilaningsih, Ilmu Pengetahuan Sosial 5 untuk SD/MI Kelas 5, Jakarta: Pusat Perbukuan Departemen Pendidikan Nasional, 2008.

[9] Sutoyo and L. Agung, Ilmu Pengetahuan Sosial 6 untuk kelas 6 SD/MI, Jakarta: CV. Sahabat, 2009.

[10] B. Rahardjo, "Sukasosial," 10 Maret 2015. [Online]. Available: http://sukasosial.blogspot.com/2015/03/jumlah-provinsi-diindonesia.html. [Accessed 22 Juni 2015].

[11] H. B. Z. Munir, Aplikasi Multimedia Dalam Pendidikan, Selangor, -

[12] S. Ariesto Hadi, Multimedia Interaktif dengan Flash, Yogyakarta: Graha Ilmu, 2003.

[13] N. S. Rahayu, Desain Multimedia, Kementrian Pendidikan dan Kebudayaan, 2013.

[14] R. Caterin, Aplikasi Multimedia Dalam Pembelajaran
Teknologi Informasi dan Komunikasi (TIK) Materi Hardware Berbasis Flash Untuk Sekolah Menengah Atas. Tugas Akhir pada Prodi Sistem Komputer FT Undip., Semarang, 2014. 